\title{
Deconstruction of Method-postmethod Dialectics in English Language Teaching
}

\author{
A B M Shafiqul Islam \\ Faculty of Languages and Translation, King Khalid University, Abha, Kingdom of Saudi Arabia \\ Israt Jahan Shuchi \\ King Khalid University, Abha, Kingdom of Saudi Arabia
}

\begin{abstract}
After a widespread dissatisfaction with the prescriptive nature of language teaching methods and approaches, the notion of postmethod emerged with an aim to providing possible solutions to the problems that both language teachers and learners face while using methods. But the transition from a long established method-based pedagogy to an emerging postmethod pedagogy could not altogether meet the expectations rather gave birth to new confusions and challenges. Therefore, this article describes the concept of method briefly and then outlines the shift from method to postmethod. This paper brings new insights into methodpostmethod dichotomy particularly by discussing the areas where the relationship between them becomes dialectical on some occasions. It also addresses the limitations of postmethod by identifying the factors where postmethod pedagogy gets entangled in a newer type of method though it emerged with the promise to come out of the stranglehold of method. Finally, it shows how postmethod redefines the traditional roles of teachers where they not only act as practitioners but also as theorizers, evaluators, observers, facilitators, innovators, and planners.
\end{abstract}

Index Terms-ELT, method, postmethod pedagogy, dialectics

\section{INTRODUCTION}

There have always been attempts to bring about qualitative changes in the field of English Language Teaching (ELT) through the introduction and adoption of new teaching approaches and methods. At the same time, these attempts also aim at the relentless search for the best method which can be made 'generalizable' and 'applicable across various contexts' (Mahdavi-zafarghandi, n. d.), the result of which a long list of methods have so far been in practice. But effective English language teaching does not depend only on the use of a method correctly by merely applying its prescribed principles and techniques (Richards \& Rodgers, 2001) but also mostly on bridging the gap between what is theorized and what is usually reflected in the classroom. Kumaravadivelu (2006, p.163) rightly mentions that methods do not always provide different pathways to language learning and teaching since there is considerable overlap in theory and practice on many occasions. So, a completely new method is not always a variation of an existing method rather is presented with a new taxonomy or, with "the fresh paint of a new terminology that camouflages their fundamental similarity" (Rivers, 1991, p. 283).

Since each new method develops on the failures of the previous method and declares the demise of the old ones, educationalists have almost stopped searching for the so-called best method, instead they now put emphasis on the harmonious application of learning principles of methods and actual practices in the classroom. Instead of method, they now prefer the term 'pedagogy' to be used and methods are viewed and criticized as unproductive and misguided (Stern, 1985, p. 251) and 'a label without substance' (Clarke, 1983, p.109) and have "little theoretical validity and even less practical utility" (Kumaravadivelu, 2006, p. 170).

Amid the deep discontent with the concept of method, postmethod pedagogy emerged as the most optimal way of teaching English with an aim to freeing teaching from the method-based stranglehold. Nunan (2003) refers to method as "a set of guidelines that describes how the language should be taught" (p. 5), and with some 'prescriptive edicts' attached to it while postmethod is based on some classroom-constructed procedures derived from the teachers' prior experiential knowledge and/or certain strategies (Kumaravadivelu, 1994, p.29) and is more a 'documentation and systematization' of the classroom practices designed according to the needs analysis of the learners (Nunan, 2004, p.177). Thus postmethod pedagogy requires us to reconsider the relationship between theorizers and practitioners of methods with rendering special emphasis on keeping teachers' sense of plausibility active so that teachers can go beyond the nomothetic tradition of mechanical practices in the classroom.

With the inception of postmethod pedagogy in English Language teaching and learning, methods are said to have moved to a complete inaction- the state that many others term as dead. The move 'beyond methods' (Richards, 1990, p. 35) has also sparked a new debate whether methods still retain any appeal in English language teaching. In this regard, David Block (2001, p.72) can rightly be mentioned who argues that method certainly retains a great deal of vitality at emic level (that is at the grassroots or to the public at large) though method may has been discredited at an etic level 
(that is in theory and in the thinking of scholars). To me, the move from method to postmethod gives birth to a lot of dialectical situations where postmethod makes frequent references to method. Although postmethod pedagogy seems to have freed us of the constraints of the concept of method thus providing new options to language teaching and teachers, the postmethod condition at the same time has brought with it its own constraints in our thinking.

Over the last few decades, we have witnessed the rise and subsequent fall of a series of methods and approaches which forced ELT researchers and practitioners to reach the conclusion that no single method or approach would bring about success in teaching a foreign language since some learners appeared to be successful regardless of methods or techniques of teaching. Moreover, many scholars harshly criticized the concept of method for its all-purpose-fit nature and cautioned the language-teaching practitioners against the uncritical acceptance of these untested methods. As a result the search for the best method came to a halt and ELT entered into a new era of moving "beyond methods" (Richards, 1990, p.35) to the "postmethod condition" (Kumaravadivelu, 1994, p.27) thus bringing new insights into ELT. To me, postmethod rather than an alternative to method, is a further updated manifestation in the search for the best method. Postmethod pedagogy does not mean the end of methods rather it involves an understanding of the limitations of the concept of method and a desire to go beyond those limitations (Bell, 2007). Although postmethod has academically put an end to method discussions and the search for the good method (Allwright, 1991; Kumaravadivelu, 1994; Prabhu, 1990), it is still a legitimate notion and very much alive to many teachers since it is a basis for building our own teaching (Bell, 2007). In the light of these, this paper discusses the concept of method and postmethod in brief and shows how method after its apparent demise still lurks inside postmethod pedagogy. This paper also endeavors to shed light on the dialectical relationship between method and postmethod pedagogy and its various manifestations.

\section{Definition of Method}

The concept of method has received much attention in the history of English language teaching. While deconstructing the concept of method, Bell (2003) defines method (with a lowercase m) as "a grab bag of classroom practices" and Method (with an uppercase M) as "a fixed set of classroom practices that serve as a prescription and therefore do not allow variation" (P. 326). He also defines method as an all-context-fit set of procedures which is actually "the oversimplified assumption of what language teachers do in the classroom" (Brown, 2000, p. 170). Richards and Rodgers (2001) consider methods "as an umbrella term comprising approach, design, and procedure" (Bell, 2003, P. 327). According to them, "a method is theoretically related to an approach, is organizationally determined by a design, and is practically realized in procedure" (Richards and Rodgers, 2001, p. 20).

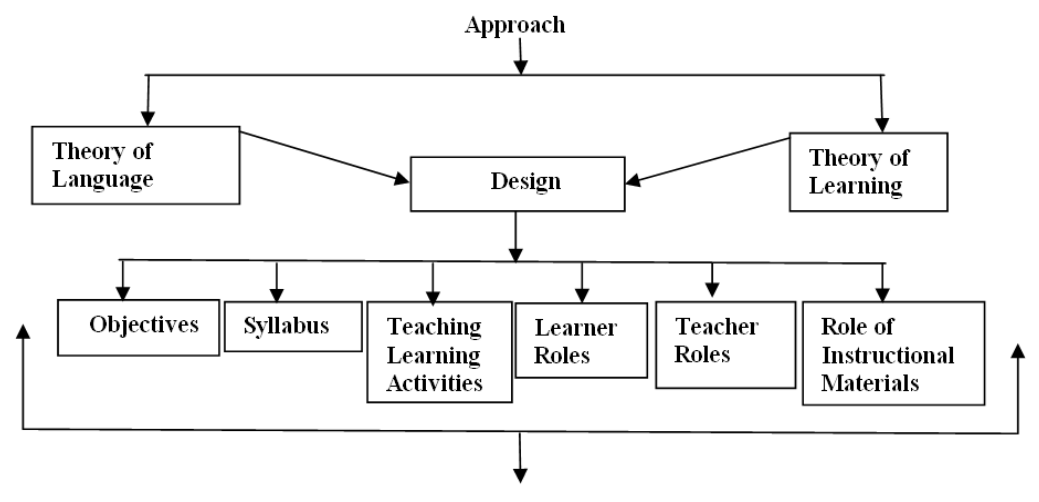

Procedure (Classroom Activities)

Diagram-1: Criteria for describing a method (based on Richards and Rodgers, 2001)

What they (Richards \& Rodgers) call 'method' is more comfortably referred to as 'methodology' by Brown (2000) in order to avoid confusion. According to Anthony (1963), method implied an overall plan for systematic presentation of language, based upon the approach and implemented through techniques consistent with the method as well as the approach. Prabhu (1990), on the other hand, uses the term 'method' to refer "both to a set of activities to be carried out in the classroom and to the theory, belief, or plausible concept that informs those activities" (p.162). Kumaravadivelu (1994) defines method as "a single set of theoretical principles derived from feeder disciplines and a single set of classroom procedures directed at classroom teachers" (p.29). Pennycook (1989) argued that methods actually serve the dominant power structures in society, leading to "a de-skilling of the role of teachers, and greater institutional control over classroom practice" (p. 610).

\section{SHIFT TO POSTMETHOD}

The concept of postmethod, a fairly new phenomenon in ELT, emerged as the most optimal way of teaching English with a view to freeing teachers from the method-based restrictions. The term 'postmethod' was first coined by Pennycook in 1989 and was later studied by many other scholars like N.S. Prabhu, R.L. Allwright, H. H. Stern, etc. But 
B. Kumaravadivelu (2006) uses postmethod condition in a much broader sense where he asks for redefining our perspectives on language teaching and teacher education. He argues that postmethod condition "drives us to streamline our teacher education by refiguring the reified relationship between theory and practice" (Kumaravadivelu, 2006, p.170). Kumaravadivelu (1994) further maintains that "if the conventional concept of method entitles theorizers to construct knowledge-oriented theories of pedagogy, the postmethod condition empowers practitioners to construct classroomoriented theories of practice. If the concept of method authorizes theorizers to centralize pedagogic decision making, the postmethod condition enables practitioners to generate location-specific, classroom-oriented innovative practices" (p. 29). The postmethod condition is a practice-driven phenomenon which always criticizes the prescriptive nature of teaching and challenges the traditional role of teachers as a mere channel of received knowledge. It also calls for empowering teachers/ practitioners by minimizing the traditional dichotomous relationship between theorizers and practitioners so that they can "theorize what they practice and practice what they theorize" (Kumaravadivelu, 2001, p.545). By refiguring the relationship between theorizers and practitioners, postmethod condition always seeks an alternative to method than any potential alternative method, encourages teachers' autonomy and believes in 'principled pragmatism'. Crandall (2000) describes this shift from method to postmethod as "a shift from transmission, productoriented theories to constructivist, process-oriented theories of learning, teaching, and teacher learning" (pp. 34-35). It shifts teaching from knowledge-oriented pedagogic theories to classroom-oriented theories of practice.

One of the most striking features within the scope of postmethod pedagogy stands out as it suggests a closer inspection of local occurrences, conditions and needs thus making teachers to be reflective in teaching. In other words, both postmethod pedagogy and reflective teaching are inextricable, intertwined and interdependent since both entertain the freedom of teachers in overcoming the constraints and limitations imposed by method. Such teachers are reflective in the sense that they observe their teaching, evaluate the results, identify problems, find solutions, and try new techniques. They are not stuck to following any single method. If they are not reflective in teaching, they "will be likely to teach as they were taught and, thus, ineffective teaching strategies will be replicated" (Braun \& Crumpler, 2004, p. 61).

Postmethod condition offers three possible frameworks to language teachers who want to follow a postmethod approach in their classrooms: Stern's (1992) Three-dimensional framework, Allwright's (2000) Exploratory Practice framework, and Kumaravadivelu's (1994) Ten Macrostrategic framework. Stern's Multi-dimensional framework is both theory neutral and method neutral where he always advocates for transcending the concept of method through an integrated curricular agenda. Allwright's Exploratory Practice (EP) always puts emphasis on ensuring teachers' understanding of the quality of classroom life rather than on developing ever 'improved' teaching methods. To him, "the central concern is a wish to offer a practical way of bringing the research perspective properly into the classroom, without adding significantly and unacceptably to teachers' workloads, so as to contribute both professional development and to theory-building within and across the profession" (Allwright, 1993, p. 131). Kumaravadivelu's (1994) Ten Macrostrategic framework shaped by three parameters of particularity, practicality, and possibility constitutes the conceptual foundation for the postmethod which is said to be both theory neutral and method neutral. But "the boundaries of the three parameters are unclear and the characteristic features of these parameters overlap. They shape and are shaped by one another" (Chen, 2014, P.18).

\section{A. Postmethod Pedagogy and Its Indicators}

The indicators of postmethod pedagogy consist of the teacher, the teacher educator and the learner. From the postmethod perspective, learners are active and enjoy autonomy through which they develop a capacity to learn using appropriate strategies and at the same time to monitor their learning process and maximize the learning potential. It also liberates from the stranglehold of methods thus empowering learners to be critical thinkers. Postmethod pedagogy also recognizes teachers' previous and current knowledge, and their potentials to teach and act autonomously, and encourages to develop a reflective approach to their own teaching by analyzing and evaluating the teaching acts, and also by initiating changes in his classroom, if necessary. "What postmethod pedagogy assumes is that the teacher will eventually construct his own theory of practice" (Kumaravadivelu, 2006, P. 180). They need to become self-directed individuals who will have clear understanding of the contextual factors. A study conducted among 18 Australian ESL teachers by Breen et al. (2001) shows that there is an interconnection between classroom practices, teacher beliefs and pedagogic principles, and their constant impact on decision making and ongoing thinking process. 


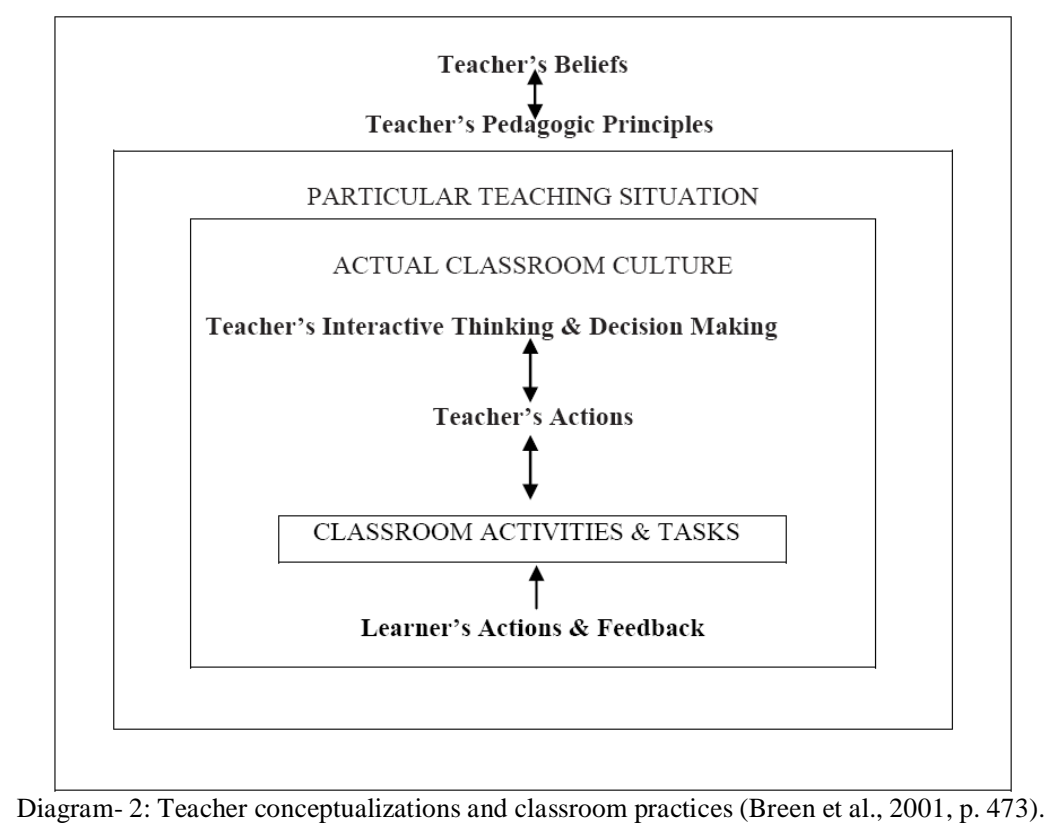

According to them, "teachers' beliefs comprise a set of guiding principles" (Kumaravadivelu, 2006, p. 179) which "mediate between the experientially informed teacher beliefs and the teacher's ongoing decision making and actions with a particular class of learners in a particular teaching situation" (p. 180). These pedagogic principles are indeed "reflexive in both shaping what the teacher does whilst being responsive to what the teacher observes about the learners' behavior and their achievements in class" (Breen et al., 2001, p. 473). In postmethod pedagogy, teachers gradually develop some kind of personal knowledge that helps them construct their own theory of practice. The task of the postmethod teacher educators is to create conditions for prospective teachers to acquire necessary authority and autonomy that will enable them to reflect on and shape their own pedagogic experiences, and in certain cases transform such experience into practice" (Kumaravadivelu, 2006, p. 182). In postmethod pedagogy, the relationship between teachers and teacher educators should be dialogic so that teachers can freely and fearlessly express their voice and exert their independent identity.

\section{B. Sense of Plausibility in Postmethod Condition}

Prabhu (1990) uses this phrase 'sense of plausibility' to refer to a subjective awareness of the context where individual teachers fashion an approach and tailor classes keeping in mind that particular context. Postmethod teachers never stick to a single set of procedures, rather they exploit and adapt their approach in accordance with local, contextual factors. The sense of plausibility basically results from a number of contributing factors including a teacher's teaching experience, his earlier learning experience as a student, and exposure to a number of methods while training as a teacher etc. Teaching can produce the best possible results only when teachers are fully involved in teaching. And this involvement becomes functional when a teacher's sense of plausibility is engaged in the teaching operation. The main thing is not "whether it implies a good or bad method but, more basically, whether the sense of plausibility is active, alive, or operational enough to create a sense of involvement for both the teacher and the student" (Prabhu, 1990, p. 173). But this sense of plausibility is greatly hampered when teaching becomes over-routinized due to the mechanical adherence to method and as a result, teaching becomes frozen, ossified, or inaccessibly submerged, leaving only a schedule of routines. According to Prabhu, the enemy of good teaching is not "a bad method, but overroutinisation".

\section{Dialectics Between Method And Postmethod}

Theoretically, postmethod marks the end of method era and disregards everything connected with method. But does post method really bring an end to method? There are some occasions when postmethod goes back with frequent reference to method thus making the dialectical relationship between method and postmethod more obscure and therefore needs further attention. Although postmethod has provided new options to ELT professionals and practitioners and brought dynamic dimensions in classroom practices thus freeing teaching from many of the constraints of the concept of method, it has brought with it its own constraints.

But in practice, postmethod does not altogether ignore the knowledge of existing methods and approaches since "experience with different approaches and methods, however, can provide teachers with an initial practical knowledge base in teaching and can also be used to explore and develop teachers' own beliefs, principles and practices" (Richards \& Rodgers, 2001, p. 252). Though postmethod pedagogy widely criticizes method for its totalizing tendency and onesize-fits-all notion, some of its positive and beneficial aspects can never be obscured. Even in the narrow sense, "methods can be seen as vehicles for innovation and challenge to the status quo" (Bell, 2003, p. 332) and they offer 
unique insights, however piecemeal and limited they may be. As vehicles for change, post method pedagogy also advocates innovation and brings challenges to the current practices of the prevailing language teaching system that go parallel with some of the traits of methods.

But Prabhu (1990), one of the proponents of postmethod pedagogy, highlights both the positive and negative effects of methods. He has described 'the negative effect as 'overroutinization' (Prabhu, 1990, P. 173), and the positive effect in terms of 'real' (P. 174) teaching. 'Real' teaching requires a sense of involvement on part of the teacher, what Prabhu calls 'a teacher's sense of plausibility" (Bell, 2003, p. 333). Though to a limited extent, methods also have the "power to influence- to invoke, activate, interact with, alter in some way, and generally keep alive- different teachers' differing senses of plausibility, thus helping to promote and enlarge the occurrence of 'real' teaching" (Prabhu, 1990, p. 175). Confusion arises when method is discarded on the ground that it is merely an act of overroutinization. But method does not merely act upon some routine activities, it also embodies real teaching where a sense of involvement is required what in post method, is termed as 'sense of plausibility'. So this sense of involvement is not a new phenomenon what post-methodologists claim to be, rather it had a place in method itself. In successful pedagogy, the most crucial thing is not the method but the teacher's passion for whatever method is adopted and the way that passion is transmitted to the learners (Block, 2001). This passion is also quiet relevant in postmethod pedagogy without which the active involvement of teachers is simply impossible. So the absolute departure from the stranglehold of method is virtually impossible. Rather, post method has extracted the good from method and devised "the tools to deconstruct their totalizing tendencies and so counter the tendency toward overroutinization" (Bell, 2003, p. 333). According to Richards and Rodgers' (2001) organizing framework, postmethod techniques and principles can better be realized within the frame of the design features (method) - teaching and learning activities, teacher/learner roles, and the role of the instructional materials. What is so interesting about this frame of design features (method) is that it contains within it the tools- learner autonomy, context sensitivity, teacher/student reflection- the sheer outcomes of postmethod pedagogy.

\section{A. Dialectics between Contexts and Methods}

The factors behind the confusing relationship between postmethod and method are neither easy to identify nor simple to assess. It becomes more acute when the notion of method is over simplified just by ignoring the complexities of the classroom. Method is intended to be blindly followed without paying any attention to contexts other than method. But in classroom teaching, there have been a lot of dependencies between contextual factors and instructional methods and these factors tend to vary in different ways in different taxonomies. Postmethod pedagogy always upholds the supremacy of contexts in language teaching and demands teaching style to be shaped in accordance with the needs of that particular context. On the contrary, methods are unidirectional and do not change whatever the context needs even if they are not compatible with the students' learning expectations. So, we should not simplify and stereotype our teaching by using some preconceived ways rather we need to clearly identify the contextual factors in the classroom. We can thus refer to varying contexts like formal environment (classroom learning), for instance, "as against learning through social exposure, or to the formal school system, as against private language instruction, or to relative formality in teacher-learner relations, as against informal relations, or even to teacher-fronted activities, as against group work among learners" (Prabhu, 1990, pp. 163-64). But there are other variables like preferred learning styles, socio-cultural influences, or personality difference, where the distinctions among them are often unclear and overlapping. Furthermore, even when some contextual factors are clearly identifiable, using instructional methods is far from clear. In classroom, students tend to employ certain natural learning strategies which do not match the teaching methods that teachers employ though learners likely to learn more by following their own strategies. But teachers consider these natural tendencies adopted by students less conducive to learning since they constitute a deviation from their preconceived, traditional and stereotyped teaching methods.

So, contextual factors should be given a central role to play in pedagogy without merely being adhered to a single method. Moreover we also need to project and determine which variations of contextual factors really matter in teaching methodology since there are "indefinite variation on many dimensions, thus making it impossible to justify any instructional method for any single group of learners" (Prabhu, 1990, p. 164). And post-methodologists mostly uphold this very point- no adherence to any single method. Thus we can assume that decisions regarding using methods in language teaching will either be rendered unnecessary or play only a small part. Though methods seem to play a small part, proponents of the postmethod pedagogy cannot completely rule out the part method usually plays even within the post method pedagogy itself. Here, Richards (1985) can rightly be mentioned who argues that "the important issues are not which method to adopt but how to develop procedures and instructional activities that will enable program objectives to be attained" (p. 42). Instructional procedures are, in effect, "a kind of discovery procedure for methods. That method is best, it seems to say, which results from a careful implementation of the procedure, the soundness of the method being guaranteed by the soundness of the procedure leading to it" (Prabhu, 1990, p. 165). And the instructional procedures are most directly derivable from the contextual specification of needs, wants, and objectives being supplied to learners. So post method does not altogether reject method rather reinforces the place of contexts in teaching that methods have ignored for long.

\section{B. Eclecticism and Principled Pragmatism}


These variations in contextual factors in language teaching ultimately minimize the possibility of adopting a single method and open up the possibility of an amalgamation of different methods what the post methodologists term as eclecticism. Eclecticism suggests liberation from a monolithic matrix, a refusal to be doctrinaire, and an espousal of plurality. Actually, in method, teachers have the fewer choices available regarding instructional procedure in accommodating these multiple contextual factors whereas eclecticism incorporates language instruction, learning needs, target needs, learners' wants, teachers' preferences, and learning styles into a mere assemblage of a completely new type of content and procedure.

Eclecticism was introduced with a good intention to promote "the careful, principled combination of sound ideas from sound sources into a harmonious whole that yields the best results" (Hammerly, 1991, p. 18). Besides having such good intentions, eclectic pedagogy carries some drawbacks with it since the implementation of eclecticism in the classroom is not as smooth as it is described in theory. Most of the time, eclecticism cannot maintain the standard of principled synthesis of sound ideas in the classroom and as a result, it often turns into an "unsystematic, unprincipled, and uncritical pedagogy" (Kumaravadivelu, 1994, p. 30). Teachers with no or very little professional preparation wish to be eclectic in a principled way which is practically impossible. Moreover, eclectic approach does not provide any concrete framework for teachers on which they can construct their own pedagogy. What they usually do is to randomly combine some techniques from various methods into a scrambled one and label it eclectic. Stern (1992) can rightly be quoted here who mentions that the "weakness of the eclectic position is that it offers no criteria according to which we can determine which is the best theory, nor does it provide any principles by which to include or exclude features which form part of existing theories or practices" (p. 11). Thus teachers in an eclectic approach go for introducing the most conducive classroom procedures of language learning from the already available methods in one specific situation. It takes all the good parts from different methods and assembles to make a new one. In that case, Bell's (2007) claim seems to be justifiable who says that methods still pervade teachers' practices. In the name of eclecticism, teachers are taking recourse to a set of methods in a blended form instead of a single method. Therefore, postmethod pedagogy in this point again fails to clarify its position and obscures its long standing stance- the complete shift from method.

Principled pragmatism emerged in postmethod pedagogy when eclecticism fails to overcome the constraints of the conventional concept of method. Mellow (2002) uses "the term principled eclecticism to describe a desirable, coherent, pluralistic approach to language teaching" (p. 1). Principled pragmatism always upholds the pragmatics of pedagogy where "the relationship between theory and practice, ideas and their actualization, can only be realized within the domain of application, that is, through the immediate activity of teaching" (Widdowson, 1990, p. 30). Principled pragmatism thus looks at classroom learning as an activity "shaped and managed by teachers as a result of informed teaching and critical appraisal" (Kumaravadivelu, 1994, p. 31). Informed teaching and critical appraisal actually include an understanding of the learners' needs, linguistic strengths and weaknesses, as well as an in-depth knowledge of the possible variations in the learners' socio-economic and cultural milieu. So, principled eclecticism eventually challenges the historical conception of method as a list of cure-all prescriptions since one method can no longer be applicable to all classroom contexts. Thus, it puts emphasis on the need to transcend the rigid notion of method though this emphasis does not altogether guarantee the complete denial of method. Rather principled pragmatism emphasizes the judicious use of the eclectic blending of useful parts of different methods according to the demand of the contexts.

So, it has been clear that post method pedagogy does not deny theory (method) because it is the only instrument through which we can make sense of complex phenomena and can reach understanding in language pedagogy. Understanding of any language gets expedited when the underlying set of ideas or principles of that language fully corresponds to making a conceptual model or theory. "If the theories of language teaching (that is to say, methods) that we have at present fail to account sufficiently for the diversity in teaching contexts, we ought to try to develop a more general or comprehensive (and probably more abstract) theory to account for more of the diversity, not reject the notion of a single system of ideas and seek to be guided instead by diversity itself. Pointing to a bewildering variety of contextual factors as a means of denying the possibility of a single theory can only be a contribution to bewilderment, not to understanding"(Prabhu, 1990, p. 165).

\section{Obsession with Methods and Postmethods}

Both methodologists and post methodologists seem to be obsessed with what they advocate for. Stern (1985) refers to the search for the ultimate method as a 'century-old obsession' (p. 251) while Kumaravadivelu (2001) considers method as having "a magical hold on us" (p. 557). Here, theorizers seem to be more obsessed than practitioners, and the obsession has become stronger even after the so-called demise of methods. Methodologists are more concerned with methods and ask practitioners to slavishly follow whatever method they have been trained in while post-methodologists show much interest in practitioners and their intellectual autonomy and discernment. But practically, both methodologists and post methodologists tend to underestimate teacher autonomy. Just as advocates of methods often think that teachers who devise their own way of teaching fail to teach systematically while post methodologists fear that teachers will slavishly follow whatever method they have been instructed to follow. Here the very conspicuous thing is that "the pessimism of both sets of theorists underestimates the intellectual autonomy and discernment of the practitioner" (Bell, 2007, p. 142). So, both methodologists and post methodologists are to some extent obsessed and stuck to their own theories (methods). 


\section{Freedom in Postmethod Pedagogy}

Postmethod theoretically frees teachers from method. But does it really free them from the stranglehold of method? In postmethod pedagogy, when teachers are to choose their own way of teaching, they cannot run the risk of choosing whatever they want since they need to keep in mind some principles and procedures necessary for conducting an effective lesson. Teachers cannot act upon their whimsicalities since their past experiences as teachers, postmethod pedagogy frameworks and their knowledge of the conventional methods function as catalysts in constructing their own methods. Their roles thus become multi-dimensional not merely being as practitioners but also as evaluators, observers, critical thinkers and theorizers. In postmethod condition, if teachers exercise much freedom in developing their own context-bound methodologies in 'my-own-method' style, they might adopt some sort of a 'hybrid' method. In other words, "the apparent freedom of choice that the postmethod condition seems to offer ELT practitioners, often results in the adoption of a jumbled concoction of techniques, which might actually represent a screen concealing teachers' limitations both to implement eclectic, principled practices that contribute to the effectiveness of the language learning process" (Soto, M. A., 2014, p. 40).

\section{Limitations of Postmethod Pedagogy}

The emergence of postmethod pedagogy in ELT carries with it lots of limitations and challenges, especially when it comes to applicability. However, implementation of postmethod pedagogy is simply impossible without building an appropriate teacher education infrastructure as well as acknowledging the limits and problems teachers confront in their actual classroom lives (Akbari, 2008). Two other major sources of barriers- pedagogical and ideological- mentioned by Kumaravadivelu (2006) also need to be addressed if we want postmethod to be accepted as the dominant L2 teacher education framework. "The pedagogical barrier relates to the content and character of L2 teacher education" which mainly deals with the mere transfer of "a set of pre-determined, pre-selected, and pre-sequenced body of knowledge from the teacher educator to the prospective teacher" (Kumaravadivelu, 2006, p. 216), and "the ideological barrier refers to the politics of representation and what counts as valid knowledge. Through a process of marginalization and self- marginalization, teachers' practical knowledge does not find the space and the scope to be regarded as visible, and consequently, fails to become part of the accepted knowledge of the discourse community" (Akbari, 2008, P.645).

The big problem is that, in postmethod pedagogy, teachers' responsibilities are much broader and other than their academic duties, they are also assigned with "extra roles of social reformer and cultural critic" thus taking "language teaching beyond the realms of possibility and practice" (Akbari, 2008, P. 645). Besides tight administrative frameworks, teachers must take into account textbooks and tests and facilities as well. "Even if teachers do not openly subscribe to a method, the textbooks they use provide them with a working plan that defines how languages are taught and learned" (Akbari, 2008, P. 645) with no extra space to act freely in a seemingly postmethod era. In many circumstances, most teachers are viewed as "servants of the system" (Shohamy, 2004, p. 106) who prepare students for a specific exam or test by just "implementing the testing policies of central agencies with no power and authority to resist" ( p. 101). Furthermore, the institutes and administrative organizations also pose potential threats to a postmethod teacher. Therefore, what Kumaravadivelu depicts about an ideal classroom environment is actually far from reality. Most of the teachers have high workloads but they are very poorly paid. Due to "the financial and occupational constraints they work within" (Akbari, 2008, p. 645), some teachers cannot devote adequate time and energy to be reflective upon their own teaching to overcome the language classroom problems in an era when there is not any method anymore. Though the postmethod pedagogy encourages teachers' autonomy and freedom of will in language classrooms, the set up acts the opposite. And teachers' lack of competence and confidence does not allow them to be bold enough to exercise freedom. It is also certain that very few postmethod teachers have the time, resources, or the willingness to shoulder responsibilities. As Akbari (2008) rightly points out "the assumption of postmethod proponents is that all teachers by default are qualified or willing to conduct a postmethod class with all its social, cognitive, political, and cultural requirements. That assumption, however, is questionable because many teachers lack the required knowledge or skill to teach in the postmethod fashion" (Akbari, 2008, p. 648).

\section{CONCLUSION}

Though postmethod emerged with the intention to be an alternative to method, not an alternative method, some deviations in their dialectical relations have really obscured that intention. As a fairly new phenomenon in English language teaching, postmethod looks at language teaching and learning from a new perspective by recognizing the potentials of practitioners to the fullest. In the above analysis, it has been clear that though postmethods have announced the academic end of the method era, methods are not altogether dead in reality, nor will they ever be. In fact, postmethod pedagogy does not "imply the end of methods but rather an understanding of the limitations of the notion of method as it is narrowly defined and a desire to transcend those limitations" (Bell, 2007, p. 143) by empowering educators towards developing a standardized system of language teaching. Efforts in developing a standard method of teaching were very much apparent during the method era but they were sporadic and ultimately resulted in failures. But postmethod pedagogy has tried to string together these diverse, piecemeal efforts in a harmonious way so that it can overcome the limitations of method. But the confusion arises when postmethod pedagogy advocates for an eclectic 
blend of different teaching ways thus reconstructing a different type of method in the name of deconstructing the totalizing tendency of method from the perspective of local contexts. Situation becomes really dichotomous when postmethod declares a complete departure from method in one hand and at the same time makes frequent references to method, on the other.

To me, the problem is not with the method rather with its prescriptive nature. Here Arikan's (2006) view is worth mentioning who opines that, in the postmethod condition, the focus should not centre on discussing methodological issues in a sporadic way, but on the ways how teachers can implement those issues in classroom practices or how they can go beyond the prevailing methods. I think that teachers should be exposed to all methods so that they themselves can choose from the existing methods or even construct what principles they will use in their teaching. By looking at both method and postmethod, I have tried to show how method still retains a place in postmethod and how postmethod makes a newer type of method in the name of eclecticism and principled pragmatism. If these confusions are clarified, "the postmethod condition can potentially reshape the character and content of L2 teaching, teacher education, and classroom research. It can empower teachers with the knowledge, skill, attitude, and autonomy necessary to devise for themselves a systematic, coherent, and relevant alternative to method" (Kumaravadivelu, 1994, pp. 43-44) than ever.

\section{REFERENCES}

[1] Akbari, R. (2008). Postmethod Discourse and Practice. TESOL Quarterly, 42(4), 641-652.

[2] Allwright, R. L. (1991). The death of the method (Working Paper \#10). The Exploratory Practice Center, University of Lancaster, England.

[3] Allwright, R. L. (1993). Integrating 'research' and 'pedagogy': Appropriate criteria and practical problems. In Edge \& K. Richards (Eds.), Teachers develop teachers' research (pp. 125-135). London: Heinemann.

[4] Allwright, R. L. (2000). Exploratory Practice: An 'appropriate methodology' for language teacher development? Paper presented at the 8th IALS Symposium for Language Teacher Educators, Scotland.

[5] Anthony, E. M. 1963. 'Approach, method and technique'. English Language Teaching 17: 63-7.

[6] Arikan, A. (2006). Postmethod condition and its implications for English language teacher education. Journal of Language and Linguistic Studies, 2(1), 1-11.

[7] Bell, D. M. (2003). Method and postmethod: are they really so incompatible? TESOL Quarterly, 37(2), 325- 336.

[8] Bell, D. M. (2007). Do teachers think that methods are dead? ELT Journal, 61(2), 135-143.

[9] Block, D. (2001). An exploration of the art and science debate in language education. In M. Bax \& J.-W. Zwart (Eds.), Reflections on language and language learning: In honour of Arthur van Essen (pp. 63-74). Amsterdam: John Benjamins.

[10] Braun, J. A. \& Crumpler, T. P. (2004). The social memoir: An analysis of developing reflective ability in a pre-service methods course. Teaching and Teacher Education, 20 (1), 59-75.

[11] Breen, M. P., Hird, B., Milton, M., Oliver, R., \& Thwaite, A. (2001). Making sense of language teaching: Teachers' principles and classroom practices. Applied Linguistics, 22, 470-501.

[12] Brown, H. D. (2000). Principles of language learning and teaching. White Plains, NY: Addison Wesley Longman.

[13] Chen, M. (2014). Postmethod Pedagogy and Its Influence on EFL Teaching Strategies. English Language Teaching, Vol. 7(5), $17-25$.

[14] Clarke, M. A. (1983).The scope of approach, the importance of method, and the nature of technique. In J. E. Alatis, H. Stern, \& P. Strevens (Eds.), Georgetown University Round Table on Languages and Linguistics 1983: Applied Linguistics and the preparation of second language teachers (pp. 106-115). Washington, DC: Georgetown University.

[15] Crandall, J. A. (2000). Language teacher education. Annual Review of Applied Linguistics, 20, 3455.

[16] Gholami, J., \& Mirzaei, A. (2013). Post-method EFL teaching in Iran: Barriers, attitudes, and symbols. Research Journal of English Language and Literature, 1(2), 50-64.

[17] Hammerly, H. (1991). Fluency and accuracy: Toward balance in language teaching and learning. Clevedon: Multilingual Matters LTD.

[18] Kumaravadivelu, B. (1994). The post method condition: (E) merging strategies for second/foreign Language Teaching. TESOL Quarterly, 28(1), 27-47.

[19] Kumaravadivelu, B. (2001). Toward a postmethod pedagogy. TESOL Quarterly, 35, 537-560.

[20] Kumaravadivelu, B. (2006). Understanding language teaching: From method to postmethod. Mahwah, NJ: Lawrence Erlbaum Associates.

[21] Mahdavi-zafarghandi, A. (n.d.). A survey of post-method in EFL [On-line]. Retrieved on January 2, 2009 from http://research.guilan.ac.ir/research/doc/c852.pdf.

[22] Mellow, J. D. (2002). Towards principled eclecticism in language teaching: The two-dimensional model and the centering principle. TESL-EJ, 5(4) A-1.

[23] Nunan, D. (2003) Practical English Language Teaching. New York: McGraw-Hill.

[24] Nunan, D (2004). Task- Based Language Teaching. Cambridge: Cambridge University Press.

[25] Prabhu, N. S. (1990). There is no best method-why? TESOL Quarterly, 24(2), 161-176.

[26] Pennycook, A. (1989). The concept of method, interested knowledge, and the politics of language teaching. TESOL Quarterly, 23(4), 589-618.

[27] Richards, J. C. (1985). The context of language teaching. Cambridge: Cambridge University Press.

[28] Richards, J. C. (1990). The language teaching matrix. Cambridge, England: Cambridge University Press.

[29] Richards, J.C., \& Rogers, T.S. (2001). Approaches and methods in language teaching (2nd ed.). New York: Cambridge University Press.

[30] Rivers, W. M. (1991). The Psychologist and the Foreign Language Teacher. Illinois: University of Chicago Press. 
[31] Shohamy, E. (2004). The power of tests over teachers: The power of teachers over tests. In D. J. Tedick, Ed.), Second language teacher education: International perspectives (pp.101-111). Mahwah, NJ: Erlbaum.

[32] Soto, M. A., (2014). P. 40). Post-method pedagogy: Towards enhanced context situated teaching methodologies: English language teaching in the post -methods era Selected papers from the 39th FAAPI Conference, pp-39-54.

[33] Stern, H. H. (1985). Review of methods that work: A smorgasbord of ideas for language teachers. Studies in Second Language Acquisition, 7(2), 249-251.

[34] Stern, H. H. (1992). Issues and options in language teaching. Oxford: Oxford University Press.

[35] Widdowson, H. G. (1990). Aspects of Language Teaching. Oxford: Oxford University Press.

A B M Shafiqul Islam has been teaching English in the Faculty of Languages and Translation at King Khalid University in Saudi Arabia since August 2012. He also worked for another three years at Jazan University in the Kingdom. His research interests include English language teaching and learning, second language acquisition and research methodology.

Israt Jahan Shuchi has been working as a lecturer in English at King Khalid University in Saudi Arabia since September 2010. She also worked for another two years at Presidency University in Bangladesh. Her research interests include phonetics and phonology, English language teaching and learning, second language acquisition and sociolinguistics. She had the experience of working as the joint treasurer and one of the executive committee members at BELTA (Bangladesh English Language Teachers' Association). 